\title{
BAHASA, SASTRA, DAN KEARIFAN LOKAL DI INDONESIA ${ }^{1)}$
}

\author{
Heddy Shri Ahimsa-Putra*)
}

\begin{abstract}
Abstrak
Dalam artikel ini dikemukakan definisi penulis tentang konsep kearifan lokal dan kearifan tradisional. Dengan menggunakan definisi kearifan lokal sebagai dasar pembahasan, penulis mencoba mengungkap berbagai kearifan lokal dalam bahasa Jawa dan sastra Jawa, Babad Tanah Jawi. Kearifan lokal yang diketemukan antara lain adalah: (a) sisipan "-in-" dalam bahasa Jawa, yang jika dimanfaatkan untuk bahasa Indonesia akan dapat mengatasi beberapa masalah dalam penerjemahan kata-kata tertentu bahasa Inggris ke dalam bahasa Indonesia; (b) beberapa istilah po-kok dalam falsafah seni tari Jawa; (c) kemampuan nalar Jawa menyatukan dua perangkat pandangan hidup dan nilai-nilai yang berbeda; (d) nilai budaya untuk me-nyelesaikan sengketa.
\end{abstract}

Kata kunci: kearifan lokal, kearifan tradisional, tari srimpi

\section{Pengantar}

Bergantinya pemerintahan Orde Baru dan krisis ekonomi di Indonesia di akhir tahun 1990an telah melahirkana beberapa perubahan penting di Indonesia, yang bibit-bibitnya sebenarnya sudah terlihat pada tahun-tahun sebelumnya. Perubahan-perubahan tersebut antara lain adalah: (1) bergantinya paradigma sistem pemerintahan, yakni dari paradigma yang sentralistis (memusat) menjadi paradigma yang desentralistis (mendaerah); (2) munculnya kesadaran akan perlunya dimensi kebudayaan dalam perencanaan dan pelaksanaan pembangunan di Indonesia; (3) munculnya kesadaran akan perlunya diperhatikan dan diberdayakan kembali kearifan-kearifan tradisional atau lokal yang dimiliki oleh berbagai komunitas dan sukubangsa di Indonesia; (4)

\footnotetext{
1) Artikel ini merupakan revisi dari makalah yang disampaikan dalam seminar nasional "Bahasa Indonesia dan Bahasa Daerah dalam Konteks Kendonesiaan II", diselenggarakan oleh Kantor Bahasa Provinsi NTB, di Mataram, Lombok, 17--18 Juni 2009.

*) Guru Besar pada Fakultas Ilmu Budaya Universitas Gadjah Mada
} 
menguatnya kesadaran akan perlunya pluralitas sosial-budaya masyarakat Indonesia dilestarikan (Ahimsa-Putra, 2007).

Perubahan yang relevan dengan pembicaraan di sini adalah perubahan yang ketiga yang berkaitan dengan kearifan lokal. Salah satu arus pemikiran yang semakin naik popularitasnya di kalangan ilmuwan sosial-budaya serta kalangan LSM di Indonesia dalam lima belas tahun terakhir ini adalah pandangan yang menekankan pada perlunya menggali kearifan-kearifan lokal di Indonesia untuk dijadikan dasar bagi pembangunan dan pengembangan masyarakat yang lebih sustainable, lebih lestari, dalam berbagai situasi dan kondisi. Kesadaran akan perlunya kearifan lokal mendapat perhatian yang lebih besar dari para ilmuwan dipicu antara lain oleh wacana global tentang kegagalan pembangunan di negara-negara dunia ketiga, oleh semakin merosotnya kualitas lingkungan alam, oleh semakin cepatnya proses kepunahan pengetahuan-pengetahuan yang menjadi basis adaptasi berbagai komunitas lokal, serta oleh semacam romantisme budaya dan kebutuhan akan adanya jatidiri di tengah arus globalisasi (Ahimsa-Putra, 2008b). Seiring dengan itu muncullah kebutuhan akan pengetahuan yang tepat dan mendalam mengenai berbagai kearifan lokal, guna dijadikan dasar bagi perencanaan pembangunan di masing-masing daerah.

Sayangnya, niat baik ini tidak mudah untuk diwujudkan karena ada sejumlah kendala. Pertama, berbagai kearifan lokal ini masih belum sepenuhnya diketahui, karena masih "terpendam" dalam budaya dan kehidupan sehari-hari masyarakat. Padahal, revitalisasi atau pemanfaatan kearifan lokal hanya akan dapat dilakukan apabila kearifan itu sendiri telah diketahui dan dipahami dengan baik. Kedua, upaya mengetahui atau menggali kearifan lokal ini hanya akan dapat dilakukan secara sistematis dan efisien jika kearifan lokal itu sendiri sudah cukup jelas maknanya, 
dan ini menuntut adanya sebuah definisi yang dapat disepakati bersama tentang apa yang dimaksud sebagai 'kearifan lokal'. Ketiga, pengetahuan dan pemahaman yang baik mengenai kearifan lokal hanya akan dapat diperoleh apabila penelitian mengenai kearifan lokal dilakukan dengan menggunakan metode dan prosedur yang tepat.

Dalam tulisan ini saya mencoba untuk menunjukkan bahwa sebagian kearifan lokal ini sebenarnya tersimpan dalam bahasa dan sastra (tertulis maupun lisan) suatu masyarakat. Hal ini berarti bahwa dengan menganalisis bahasa dan sastra ini akan dapat diungkapkan berbagai kearifan lokal suatu masyarakat, yang kemudian akan dapat direvitalisasi untuk kepentingan masyarakat itu sendiri. Pertanyaannya kemudian adalah: apa yang dimaksud dengan kearifan lokal? Bagaimana menganalisis bahasa dan sastra untuk mendapatkan kearifan lokal tersebut? Inilah beberapa pertanyaan yang akan berusaha dijawab dalam tulisan ini.

Untuk mengungkap kearifan lokal yang terdapat dalam bahasa di sini digunakan cara analisis komponen, yang memilah-milah sebuah unit kebahasaan menjadi unsur-unsur yang membentuknya, dan analisis semantik, yang ditujukan untuk mengetahui makna-makna kata-kata dalam bahasa lokal yang terdapat pada suatu lapangan tertentu. Analisis hermeneutik, tafsiriah, digunakan untuk dapat memberikan tafsir yang sesuai terhadap wacana atau episode karya sastra yang dihadapi.

\section{Pembahasan}

\subsection{Kearifan Tradisional, Kearifan Kini, dan Kearifan Lokal}

Kearifan lokal sebagai sebuah konsep ilmiah sering disamakan dengan kearifan tradisional. Padahal keduanya jelas berbeda. Sebuah kearifan lokal, belum tentu merupakan kearifan tradisional. Demikian 
pula, sebuah kearifan tradisional belum tentu merupakan sebuah kearifan lokal. Apa yang dimaksud dengan 'kearifan tradisional', dan apa yang dimaksud dengan 'kearifan lokal'?

Setahu saya sampai saat ini belum ada definisi yang cukup memuaskan mengenai kearifan lokal dan kearifan tradisional. Sejumlah definisi memang telah dikemukakan tetapi masing-masing mengandung kelemahan tertentu yang tidak dapat saya bahas di sini. Saya akan membahas pengertian dua istilah tersebut dari segi bentukan bahasanya terlebih dahulu, kemudian makna kata-kata yang ada di $\operatorname{situ}^{2)}$, dan kemudian memberikan definisi serta penjelasannya (lihat Ahimsa-Putra, 2008).

\subsubsection{Kearifan Tradisional dan Kearifan Kini}

Frasa 'kearifan tradisional' terdiri dari kata benda dan kata sifat. Kata sifat di situ adalah 'tradisional' yang menerangkan kata 'kearifan'. Kata 'kearifan' sendiri berasal dari kata sifat 'arif' yang berasal dari bahasa Arab (?), yang artinya tidak lain adalah 'tahu' dan 'mengetahui'. Dari kata ini dalam bahasa Indonesia diperoleh kata 'mengarifi' yang berarti 'mengetahui', 'memahami'. Jadi, 'kearifan' sebenarnya dapat kita artikan sebagai 'pengetahuan'. Kearifan tradisional tidak lain adalah 'pengetahuan tradisional'.

Akan tetapi, dalam bahasa Indonesia kata 'arif' juga memiliki makna yang lebih luas, yang mencakup pengertian 'bijaksana', karena 'arif' juga dapat bermakna 'cerdik pandai' 'bijaksana', 'berilmu'. 'Bijaksana' dalam bahasa Indonesia berarti ‘selalu menggunakan budinya

\footnotetext{
2) Penjelasan dari segi bentukannya dan makna kata saya ambil dari Kamus Umum Bahasa Indonesia oleh W.J.S.Poerwadarminta, yang diolah kembali oleh Pusat Pembinaan dan Pengembangan Bahasa, De-partemen Pendidikan dan Kebudayaan, dan diterbitkan oleh Balai Pustaka (1985).
} 
(pengalamannya dan pengetahuannya)'. Selain itu, makna 'bijaksana' juga dapat kita ketahui dari kata turunannya, 'kebijaksanaan'. Kata ini diartikan antara lain sebagai "kepandaian menggunakan akal budi"; "pimpinan dan cara bertindak" dan "kecakapan bertindak bila menghadapi orang lain (kesulitan, dsb.)" (Poerwadarminta, 1985 :138). Jadi, 'bijaksana' dapat kita artikan sebagai “cakap atau pandai dalam mengatasi kesulitan".

Berkenaan dengan kesulitan yang ada hubungannya dengan orang lain, 'bijaksana' di sini juga mengandung arti dapat menyelesaikan persoalan tanpa menyakiti (fisik ataupun perasaan) orang lain tersebut, sedang berkenaan dengan kesulitan yang ada hubungannya dengan lingkungan fisik, 'bijaksana' di situ mengandung pengertian dapat menyelesaikan persoalan tanpa menimbulkan kerusakan fisik atau kerugian material. Inilah yang biasa dimaksud sebagai "penyelesaian yang bijaksana" atau "penyelesaian secara baik dan benar". Dikatakan 'baik', karena tidak merugikan atau menyakiti pihak lain, tidak merusak lingkungan, dan dikatakan 'benar' karena persoalannya kemudian bisa selesai.

Atas dasar pembahasan di atas, kita dapat mendefinisikan 'kearifan' sebagai 'perangkat pengetahuan dan praktek-praktek untuk menyelesaikan persoalan dan/atau kesulitan yang dihadapi dengan cara yang baik dan benar'. Saya gunakan kata 'perangkat' di sini untuk menunjukkan bahwa 'pengetahuan' tersebut terdiri dari berbagai unsur dan membentuk suatu kesatuan. Saya tidak menggunakan kata 'sistem' karena konsep ini saya anggap tidak terlalu cocok untuk apa yang saya maksudkan. Kata 'perangkat' (set) saya anggap lebih cocok, karena di situ terkandung pengertian : (a) adanya unsur-unsur; (b) adanya hubungan antarunsur tetapi tidak bersifat empiris; (c) hubungan 
antarunsur juga tidak mekanis ataupun fungsional; (d) membentuk suatu kesatuan tanpa harus ada batas-batas empiris yang jelas untuk satuan ini. Tiga unsur yang terakhir (b), (c) dan (d) adalah yang membuat konsep 'perangkat' berbeda dengan konsep 'sistem' (Ahimsa-Putra, 2008).

Kata berikutnya adalah 'tradisional'. Kata ini berasal dari bahasa Inggris, traditional, yang artinya 'berkaitan atau ada hubungannya dengan tradisi'3). Kata 'tradisi' dalam bahasa Indonesia dapat dianggap berasal dari bahasa Belanda, traditie, atau dari bahasa Inggris, tradition . Jika kata tersebut dianggap berasal dari bahasa Inggris (yang maknanya saya kira tidak akan terlalu berbeda dengan makna traditie dalam bahasa Belanda), maka kata tradition mempunyai banyak arti. Beberapa di antaranya adalah (1) "The action of handing over (something material) to another"; (2) "Delivery esp. oral delivery of information or instruction"; (3) "The act of transmitting or handing down or fact being handed down, from one to another or from generation to generation"; (4) "transmission of statements, beliefs, rules, customs or the like, esp. by word of mouth, or by practice without writing"; (5) "That which is thus handed down"; (6) "a statement, belief or practice transmitted (esp. orally) from generation to generation."; (7) “A long established and generally accepted custom, or method of procedure, having almost the force of a law".

Dari beberapa makna di atas kita melihat bahwa 'tradisi' atau tradition bisa berarti (a) suatu tindakan, bisa pula berarti (b) sesuatu yang dikenai tindakan tersebut. Sebagai (a) tindakan, 'tradisi' berarti "memberikan sesuatu yang bersifat materiel kepada yang lain"; "pemberian informasi atau instruksi"; "tindakan memindahkan atau

\footnotetext{
3) Uraian tentang makna kata tradition dan traditional dalam bahasa Inggris saya ambil dari The Shorter Oxford English Dictionary on Historical Princiles, edisi ke III, Clarendon Press, Oxford (1973).
} 
memberikan dari satu orang ke orang lain, dari satu generasi ke generasi yang lain; "pemindahan atau pemberian pernyataan, kepercayaan, aturan, kebiasaan atau sejenisnya, terutama dari mulut ke mulut (secara lisan) atau dengan praktek tanpa tulisan".

Sebagai (b) sesuatu yang dikenai tindakan, 'tradisi' berarti "sesuatu yang diwariskan"; "suatu pernyataan, kepercayaan, atau praktek yang dipindahkan (diwariskan) dari generasi ke generasi"; "suatu adatistiadat atau metode prosedur yang sudah lama mapan dan diterima umum, yang kekuatannya hampir seperti hukum". Selanjutnya, traditional dalam bahasa Inggris berarti "Belonging to, consisting in, or of the nature of tradition; handed down by or derived from tradition", atau "termasuk atau memiliki sifat seperti tradisi; diturunkan atau berasal dari tradisi". Dari berbagai arti mengenai tradition tersebut saya merasa bahwa 'tradisi' dalam bahasa Indonesia biasanya diartikan sebagai "suatu kebiasaan yang sudah turun-temurun atau diwariskan dari generasi ke generasi" (Ahimsa-Putra, 2007).

Dengan memperhatikan makna dalam bahasa Indonesia dan bahasa Inggris tersebut, kita dapat dengan lebih seksama mendefinisikan tradisi sebagai sejumlah kepercayaan, pandangan, nilai-nilai dan berbagai praktek yang diwariskan dari generasi ke generasi tidak melalui tulisan (biasanya secara lisan atau lewat contoh tindakan), yang diterima oleh suatu masyarakat atau komunitas sehingga menjadi mapan dan mempunyai kekuatan seperti hukum. Dari arti ini, istilah 'tradisional' dapat kita artikan "yang telah diwariskan dari generasi ke generasi dan diterima oleh umum". "Diterima oleh umum" di sini artinya dimengerti, dipahami artinya dan disetujui, disepakati oleh banyak orang pelaksanaan atau penerapannya dalam kehidupan sehari-hari. "Mempunyai kekuatan seperti hukum" artinya pelanggaran atau penolakan atas kepercayaan, 
pandangan, nilai-nilai dan praktek yang telah disepakati akan dapat menyebabkan diterapkannya hukuman-hukuman tertentu kepada individu pelanggar atau penolaknya.

Selain itu, -walaupun tidak sepenuhnya tepat- 'tradisional' juga sering dipertentangkan dengan (a) 'modern' (masa kini, kontemporer); (b) 'Barat' dan (c) universal. Oleh karena itu, 'tradisional' kadangkadang diartikan sebagai 'kuno', 'tidak modern', dan karena itu pula sering diasosiasikan, dihubungkan, dengan 'ketinggalan zaman', 'tidak maju', 'tidak menarik'. Kadang-kadang pula 'tradisional' dikaitkan dengan 'dunia Timur' yang berlawanan dengan 'dunia Barat'. 'Tradisional' juga seringkali dihubungkan dengan sesuatu yang bersifat 'lokal', sehingga kemudian dipertentangkan dengan sesuatu yang bersifat 'universal'.

Berdasarkan atas berbagai makna dari kata-kata 'arif', 'tradisi' dan 'tradisional' di atas, kini kita dapat mendefinisikan kearifan tradisional sebagai perangkat pengetahuan dan praktek pada suatu komunitas untuk menyelesaikan secara baik dan benar persoalan dan/atau kesulitan yang dihadapi, serta diperoleh dari generasi-generasi sebelumnya secara lisan atau melalui contoh tindakan, yang memiliki kekuatan seperti hukum maupun tidak. Lebih dari itu, kata 'kearifan' juga dapat diartikan sebagai 'kemampuan untuk mengambil tindakan yang baik dan benar'. Kemampuan tersebut pada dasarnya adalah pengetahuan untuk menentukan tindakan-tindakan yang dipandang tepat, guna menyelesaikan masalah-masalah tertentu.

Kearifan tradisional berbeda dengan kearifan masa kini (kontemporer). Kearifan masa kini atau kearifan kini dapat didefinisikan sebagai perangkat pengetahuan dan praktek pada suatu komunitas untuk menyelesaikan secara baik dan benar persoalan dan/atau kesulitan yang 
dihadapi, yang diperoleh dari komunitas, masyarakat atau suku-bangsa lain di masa kini, baik secara lisan atau melalui contoh tindakan, yang memiliki kekuatan seperti hukum maupun tidak.

\subsubsection{Kearifan Lokal}

Kearifan tradisional dan kearifan kini berbeda dengan kearifan lokal. Pada kearifan lokal penekanan diberikan pada tempat, lokalitas, dari kearifan tersebut, sehingga kearifan lokal tidak harus merupakan sebuah kearifan yang telah diwariskan dari generasi ke generasi. Kearifan lokal bisa merupakan kearifan yang belum lama muncul dalam suatu komunitas, sebagai hasil dari interaksinya dengan lingkungan alam dan interaksinya dengan masyarakat dan budaya lain. Oleh karena itu kearifan lokal tidak selalu bersifat tradisional, karena dia dapat mencakup kearifan masa kini, dan karena itu pula bisa lebih luas maknanya daripada kearifan tradisional. Untuk membedakan kearifan lokal yang baru saja muncul dalam suatu komunitas dengan kearifan lokal yang sudah lama dikenal komunitas tersebut, kita dapat menyebutnya "kearifan kini", "kearifan baru", "kearifan kontemporer", dan "kearifan tradisional" dapat pula kita sebut "kearifan dulu" atau "kearifan lama".

Kearifan lokal mencakup berbagai pengetahuan, pandangan, nilai serta praktek-praktek dari sebuah komunitas baik yang diperoleh dari generasi-generasi sebelumnya dari komunitas tersebut, maupun yang didapat oleh komunitas tersebut di masa kini, yang tidak berasal dari generasi sebelumnya, tetapi dari berbagai pengalaman di masa kini, termasuk juga dari kontaknya dengan masyarakat atau budaya lain. Oleh karena itu kearifan lokal dapat didefinisikan sebagai perangkat pengetahuan dan praktek-praktek pada suatu komunitas -baik yang berasal dari generasi-generasi sebelumnya maupun dari pengalamannya 
berhubungan dengan lingkungan dan masyarakat lainnya- untuk menyelesaikan secara baik dan benar persoalan dan/atau kesulitan yang dihadapi, yang memiliki kekuatan seperti hukum maupun tidak.

Atas dasar uraian di atas dapat kita peroleh skema kearifan sebagai berikut.

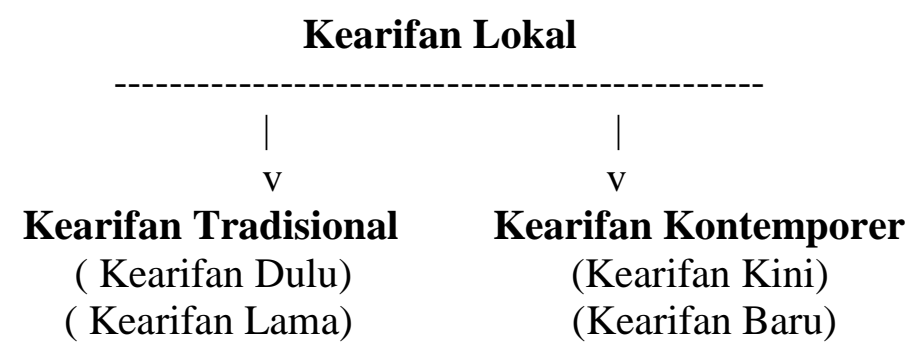

Mengingat bahwa konsep kearifan lokal merupakan konsep yang lebih luas, yang bisa mencakup kearifan tradisional maupun kearifan di masa kini, maka istilah kearifan lokal inilah yang sebaiknya digunakan dalam wacana ilmiah tentang kebudayaan dan pembangunan. Selain itu konsep kearifan lokal juga dapat menghindarkan kesan bahwa kearifan tersebut masih "tradisional” atau kuno, yang mudah menimbulkan kesan negatif, yang dapat membuat orang tidak begitu berminat untuk menggali dan memahami pengetahuan-pengetahuan lokal yang ada dalam masyarakat mereka.

Dalam kaitannya dengan 'kebudayaan', 'kearifan lokal' sebagai perangkat pengetahuan dengan sendirinya merupakan bagian dari kebudayaan yang bersifat abstrak. 'Kearifan lokal' juga merupakan perangkat simbol. Simbol-simbol ini bisa bermakna 'baik', 'positif', bisa pula 'tidak baik', 'negatif'. Di Indonesia, 'kearifan lokal' jelas mempunyai makna positif, karena 'kearifan' selalu dimaknai secara 'baik' atau 'positif'. Pemilihan kata ini sendiri -disadari atau tidakmerupakan sebuah strategi untuk membangun, menciptakan citra yang lebih baik mengenai 'pengetahuan lokal', yang memang tidak selalu 
dimaknai secara positif. Dengan menggunakan istilah 'kearifan lokal' sadar atau tidak- orang lantas bersedia menghargai 'pengetahuan tradisional', 'pengetahuan lokal' warisan nenek-moyang dan kemudian bersedia bersusah-payah memahaminya untuk bisa memperoleh berbagai kearifan yang ada di situ, yang mungkin relevan untuk kehidupan manusia di masa kini dan di masa yang akan datang.

Di mana kearifan-kearifan lokal ini tersimpan? Bagaimana cara menemukan atau menggalinya? Sebagian kearifan ini tersimpan dalam bahasa dan sastra (lisan dan tertulis) suatu masyarakat.

\subsection{Bahasa dan Kearifan Lokal}

Kearifan lokal ini tidak harus berupa pengetahuan yang disadari. Dia bisa berupa unsur-unsur budaya lokal yang dapat digunakan untuk menyelesaikan masalah-masalah. Potensi unsur budaya lokal untuk menyelesaikan masalah ini mungkin sama sekali tidak diketahui oleh masyarakat pendukung budaya itu sendiri. Tugas para ilmuwan budayalah untuk dapat mengungkapkan potensi tersebut dan menunjukkan sumbangannya bagi penyelesaian masalah-masalah yang dihadapi.

Di sini diberikan dua buah contoh dari "kearifan lokal" yang tersimpan dalam bahasa lokal, yang saya kira potensinya tidak disadari atau belum diketahui oleh masyarakat pemilik bahasa itu sendiri. Kearifan lokal ini dapat memberikan sumbangan penting bagi pengembangan budaya Indonesia, khususnya bahasa Indonesia.

\subsubsection{Sisipan "-in” Dalam Bahasa Daerah}

Dalam bahasa daerah di Indonesia (seperti bahasa-bahasa Minahasa dan bahasa Jawa, dan mungkin pada beberapa bahasa daerah yang lain) 
dikenal adanya sisipan '-in', yang tidak terdapat dalam bahasa Indonesia, yang berasal dari bahasa Melayu. Dalam pandangan saya sisipan "-in-" merupakan sebuah potensi budaya, sebuah kearifan lokal yang tidak disadari potensinya, namun dapat digunakan untuk menyelesaikan masalah dalam penerjemahan. Jika disepakati dan dimanfaatkan dengan baik, potensi ini akan dapat membuat bahasa Indonesia menjadi lebih berkembang, dan juga membuatnya lebih berakar pada bahasa daerah yang bukan-Melayu. Saya akan memberikan contoh dari apa yang saya alami dan kemudian lakukan ${ }^{4}$.

Ketika saya mulai memperkenalkan paradigma strukturalisme Lévi-Strauss di Indonesia, salah satu kesulitan utama saya antara lain adalah mengIndonesiakan beberapa konsep atau istilah yang sudah begitu umum digunakan dalam bahasa Inggris. Dua di antaranya adalah istilah signified dan signifier. Sebenarnya sudah ada padanan kata bahasa Indonesia untuk dua istilah tersebut -yakni petanda dan penanda-, tetapi cukup sulit bagi saya untuk menerima petanda sebagai terjemahan dari signified. Dalam pemahaman saya, signified adalah "yang ditandai", sedang kata petanda lebih mengacu pada "yang menandai" atau pelaku, sebagaimana halnya kata petembak, pebola, petinju, pedayung, dan sebagainya.

Sementara itu dalam bahasa daerah seperti bahasa Jawa ada sisipan "-in-", yang dalam penggunaannya menunjuk pada keinginan untuk memberikan tindakan tertentu pada suatu obyek, seperti misalnya kata tinendang (t-in-endang), kineplak (k-in-eplak), ji-niwit (j-in-iwit), jinambak (j-in-ambak). Sisipan “-in” di sini setidak-tidaknya menunjukan adanya suatu obyek yang ingin dikenai tindakan tertentu. Di sini

\footnotetext{
4) Saya minta maaf jika dalam hal ini saya berbeda pendapat dengan teman-teman saya yang ahli bahasa, yang lebih mengetahui tentang seluk-beluk perbahasaan.
} 
sisipan "-in-" memberikan makna pasif pada sesuatu, yang dekat dengan makna akhiran "-ed” dalam bahasa Inggris, seperti signified, wanted, worshiped dan sebagainya. Dengan mengambil sebagian makna sisipan 'in-' dalam bahasa Jawa (yang mungkin juga ada dalam bahasa daerah yang lain), maka 'signified' kemudian dapat diterjemahkan menjadi 'tinanda' (t-in-anda).

Dengan memanfaatkan sisipan '-in-" tersebut maka bahasa Indonesia akan memiliki beberapa keuntungan. Pertama, bahasa Indonesia dapat menjadi lebih produktif karena bahasa Indonesia akan mudah menciptakan kata-kata baru dengan makna yang baru, yang lebih praktis daripada kata-kata yang sudah ada sebelumnya. Sebagai contoh, kata signified dalam bahasa Inggris kemudian dapat diterjemahkan menjadi 'tinanda', dan ini lebih praktis daripada 'yang ditandai'. Pola penambahan sisipan '-in-' ini dapat diterapkan pada kata-kata yang kurang lebih sejenis.

Kedua, bahasa Indonesia juga dapat menjadi lebih logis dan konsisten. Dengan memanfaatkan sisipan '-in-', maka awalan 'pe-' dapat digunakan hanya untuk pelaku, sehingga bisa diperoleh kata-kata dengan awalan 'pe-' tanpa sengau dan awalan 'pe-' dengan sengau, jika dihubungkan dengan kata lain. Seperti misalnya, petembak dan penembak, petinju dan peninju, pebalap dan pembalap, petuduh dan penuduh, petuntut dan penuntut, dan seterusnya. Dua kata yang berpasangan ini mempunyai makna yang berbeda. Kelompok yang pertama (kata dengan awalan 'pe-' tanpa sengau) berarti 'orang yang mempunyai pekerjaan sebagai' (profesi), sedang kelompok kedua (kata dengan awalan 'pe-' dengan sengau) berarti 'orang yang melakukan tindakan'. Sementara itu dengan sisipan '-in- ‘ kita bisa memperoleh katakata, tinembak (yang ditembak), tininju (yang ditinju), pinukul (yang 
dipukul), tinuduh (yang dituduh), tinuntut (yang dituntut) dan seterusnya. Dengan demikian bahasa Indonesia akan menjadi lebih kaya, sekaligus juga bisa lebih praktis dalam penggunaan sejumlah kata di dalamnya.

Mungkin akan ada yang mengatakan bahwa kata-kata tersebut terdengar aneh dan tidak lazim, sehingga kurang setuju dengan pandangan di atas. Mengenai alasan "terdengar aneh", hal itu karena kata-kata tersebut masih baru dan kita belum terbiasa. Jika sudah lama, kita akan terbiasa juga nantinya, dan kemudian dapat menerimanya. Banyak sekali kata-kata baru dalam bahasa Indonesia sekarang ini yang tidak ada dan tidak biasa di tahun 1970an. Misalnya saja kata-kata: swalayan, canggih, kudapan, nirlaba, pesohor dan sebagainya. Kini, katakata ini sudah biasa kita dengar, dan akhirnya dapat kita terima.

Mungkin juga ada yang berpendapat bahwa hal seperti itu menyalahi kaidah dalam bahasa Melayu. Masalahnya adalah: apakah kita tidak boleh memanfaatkan potensi-potensi kebahasaan yang ada dalam bahasa daerah yang lain untuk mengatasi masalah-masalah tertentu dalam bahasa Indonesia, yang tidak dapat dipecahkan lewat bahasa Melayu? Mestinya sangat boleh, dan sangat dianjurkan, dan potensi yang dimanfaatkan tersebut mestinya juga bukan hanya pada tataran lexicon saja, tetapi juga pada tataran tata bahasa. Oleh karena itulah, sisipan '-in' yang ada dalam beberapa bahasa daerah di Indonesia perlu dimanfaatkan.

Itulah kearifan lokal yang terdapat dalam bahasa, pada tataran yang tidak disadari oleh para pendukung bahasa itu sendiri. Para peneliti bahasa dapat mengungkapkan hal-hal semacam ini, dan para pembuat kebijakan dalam bidang bahasa dapat memanfaatkan data kebahasaan ini untuk membantu mereka menyelesaikan masalah-masalah kebaha-saan. Apa yang saya sampaikan di atas hanyalah sebuah pemikiran atau 
masukan. Apa-kah masukan tersebut akan diterima, itu terserah kepada pihak-pihak yang lebih mempunyai wewenang.

Ada baiknya diingat di sini bahwa -sebagaimana telah diajarkan oleh de Saussure (1967)-, dalam bahasa tidak pernah ada hubungan intrinsik antara tinanda dengan petanda atau penandanya.. Hubungan di antara keduanya bersifat arbitrair (arbitrary), semena-mena dan didasarkan pada kesepakatan (consensus). Oleh karena itu, kalau kita memang sepakat dengan pendapat di atas, maka jadilah. Kesepakatan tersebut saya kira akan banyak membawa manfaat untuk bahasa Indonesia, karena dengan begitu kita akan memperoleh daftar kata baru dalam bahasa Indonesia, yang jika dimanfaatkan dapat menghemat ruang, dan juga menguatkan prinsip keajegan dalam berbahasa, yang berarti juga keajegan dalam berfikir.

Berikut adalah beberapa contoh kata yang dibentuk dengan sisipan/awalan '-in-' dan maknanya. 
45 Mabasan - Vol. 3 No. 1 Januari-Juni 2009: 30--57

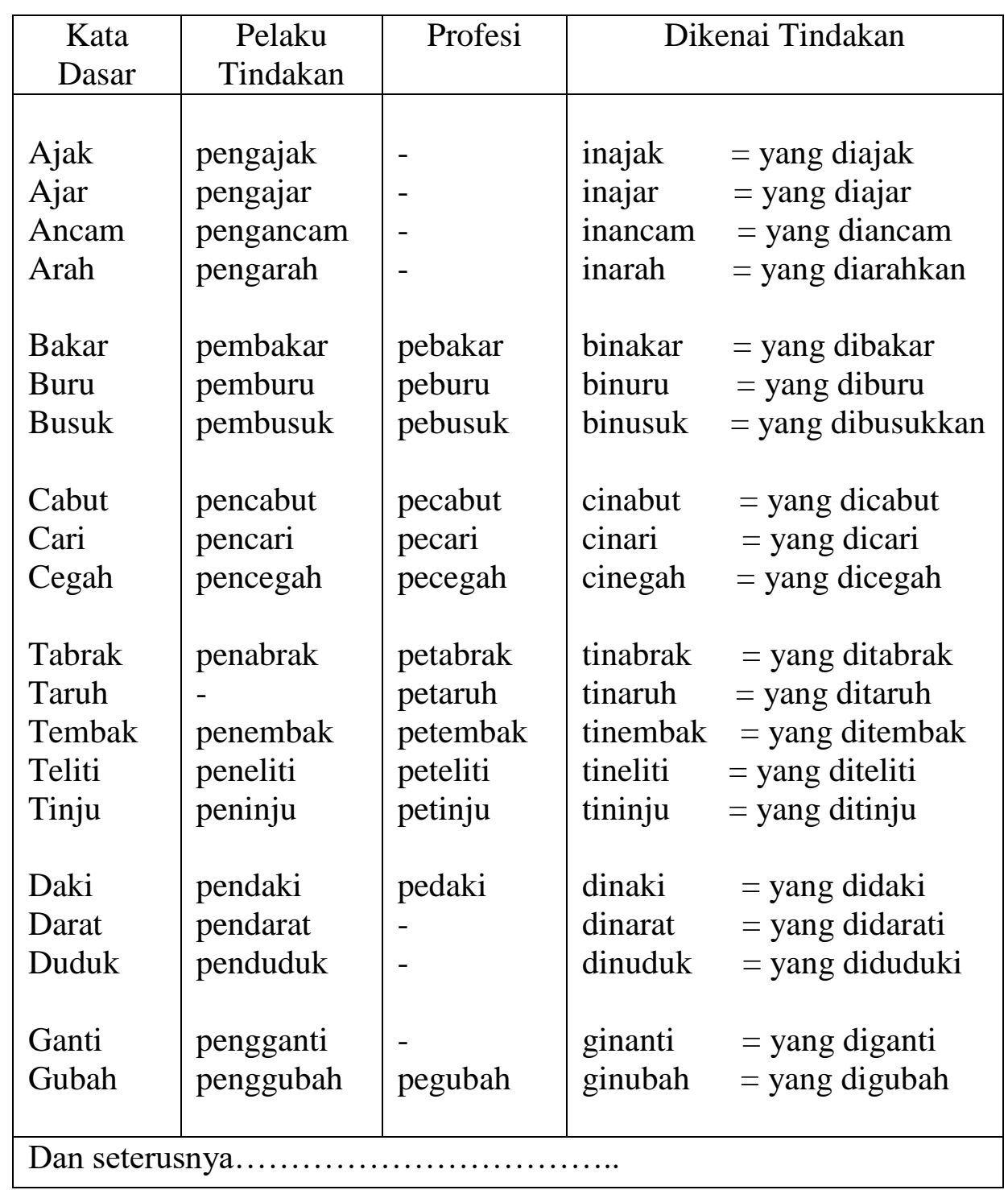

Mungkin juga usulan seperti di atas telah pernah diajukan oleh pakar bahasa yang lain. Seandainya demikian, maka masukan saya ini dapat dianggap sebagai penguatan atas masukan sebelumnya itu, tetapi kalau masukan seperti itu belum pernah ada, maka masukan ini memang merupakan hal yang baru, dan sebaiknya dapat dipertimbangkan tentang diterima-tidaknya. 


\subsubsection{Istilah-istilah dalam Kesenian}

Kearifan lokal yang terdapat dalam bahasa juga tersimpan dalam istilah-istilah bahasa daerah, yang tidak selalu dapat diterjemahkan ke dalam bahasa Indonesia. Kosa-kata bahasa daerah ini dapat dimanfaatkan untuk menerjemahkan kata-kata asing yang mungkin tidak ada padan katanya dalam bahasa Melayu. Jika tidak, kata-kata ini sendiri sebenarnya juga mengandung pengetahuan-pengetahuan tertentu yang khas, milik pemakai bahasa tersebut, yang biasanya tidak terdapat dalam perangkat pengetahuan masyarakat yang lain. Sebagai contoh saya akan mengambil istilah-istilah yang terdapat dalam khasanah seni tari, khususnya tari Jawa.

Salah satu tari yang populer di kalangan orang Jawa adalah tari Srimpi. Dalam pandangan orang Jawa, tarian ini merupakan ekspresi, wujud, dari keseimbangan antara baik dan buruk, gelap dan terang, bumi dan langit. Srimpi itu sendiri bermakna "empat arah mata angin" (Suharto, 1995). Tarian srimpi merupakan simbol dari empat arah mataangin tersebut, yakni: utara, selatan, timur dan barat, serta simbol dari empat unsur yang universal, yaitu: api, udara, air dan tanah. Dari sini kita bisa mengerti mengapa empat penari srimpi mengenakan pakaian yang seragam (sama) dan mereka terlibat dalam konflik simbolis yang tidak dimenangkan oleh siapapun karena semuanya memiliki kekuatan yang sama. Seimbang.

Seorang penari srimpi yang memahami filosofi tarian ini harus berusaha untuk menggunakan konsep 'keseimbangan' Jawa sebagai sumber kekuatannya ketika menari, sehingga tujuan seseorang menari bukanlah untuk mencapai kehebatan dalam menari atau menjadi lebih baik daripada penari yang lain, tetapi untuk terus-menerus memperdalam kemampuan mengekspresikan diri. Bahkan ketika dia telah menjadi 
seorang penari yang mahir, inipun tetap perlu terus dilakukan (Suharto, 1995). Mungkin karena maknanya yang dalam inilah maka tari srimpi ini dulu rasanya begitu populer.

Selanjutnya model empat yang manunggal di atas juga terdapat dalam konsep orang Jawa tentang joged Mataram yang menurut pangeran Suryobrongto mengandung empat prinsip dasar, yakni:(1) sawiji (perhatian memusat, konsentrasi); (2) greget (dinamika dalam, tanpa kekasaran); (3) sengguh (yakin pada diri-sendiri, tanpa disertai kesombongan); ora mingkuh (disiplin, pantang mundur). Empat prinsip ini merupakan unsurunsur dari joged Mataram pada bidang wirasa, yang jika digambarkan akan tampak seperti berikut.

\section{Diagram I: Bagian-bagian Wirasa Joged Mataram.}

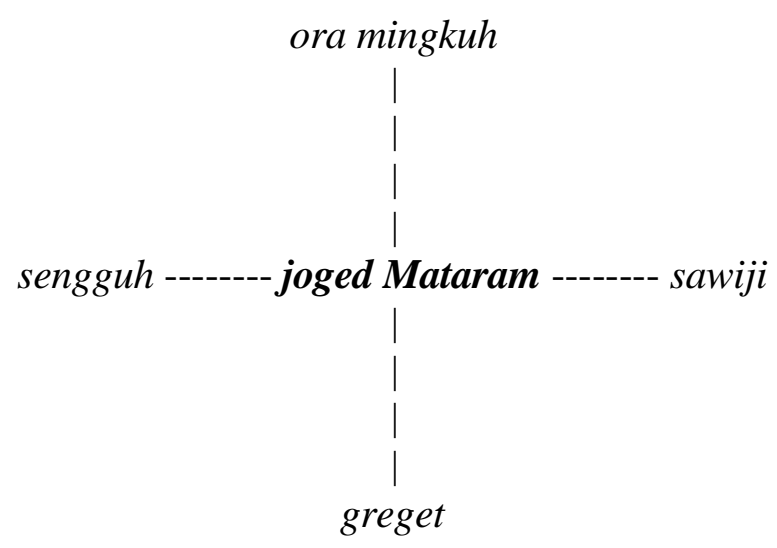

Model semacam ini juga terdapat dibalik definisi Suryadiningrat mengenai tari yang menurut beliau mencakup tiga elemen: (1) wiraga, yang artinya keseluruhan gerak tubuh penari; (2) wirama, yaitu iringan untuk tarian berupa suara gamelan dan iramanya, dan (3) wirasa, yaitu harmoni antara ekspresi wajah atau simbol, dan makna dari tarian itu sendiri. Pada bidang wirama terdapat dua elemen, yakni: (a) ungel, suara gamelan (misalnya dari instrumen bonang, saron dan sebagainya), dan (b) 
wirama, irama gamelan (misalnya cepat atau lambat). Pada bidang wirasa juga terdapat dua elemen, yakni: (a) pasemon atau lambang, dan (b) pikajeng, yaitu makna atau maksud dari tarian.

Dua elemen tersebut ungel dan wirama, pasemon dan pikajengditafsirkan oleh Suharto sebagai wujud dari oposisi berpasangan: yang terbatas dan yang tidak terbatas, atau mikrokosmos dengan makrokosmos. Ungel merupakan sesuatu yang tidak terbatas, sedang irama terbatas. Pada tataran wirasa, elemen pasemon merupakan yang terbatas. Pasemon adalah ekspresi wajah, yang dalam tari Yogyakarta dianggap sebagai sesuatu yang terbatas, karena penari tidak diperbolehkan memperlihatkan perasaan mereka, situasi dalam diri mereka, lewat wajah mereka. Dasar pandangannya adalah, perasaan yang kuat akan dengan sendirinya terekspresikan, terwujud, dalam wajah dan gerak (Suharto, 1995 :16).

Jika unsur-unsur yang berlawanan namun berpasangan tersebut digambarkan dengan menggunakan model seperti di atas, maka akan diperoleh diagram sebagai berikut.

\section{Diagram II: Unsur-unsur Pembentuk Joged Mataram}

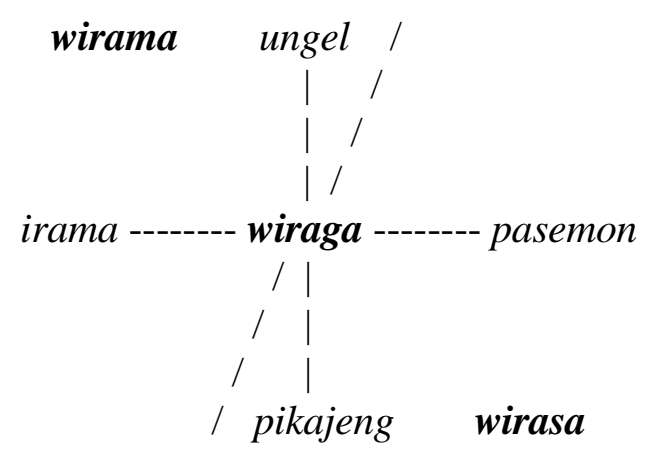

(Sumber: Suharto, 1995: 22, dengan sedikit perubahan dari penulis).

Dari paparan di atas terlihat bahwa istilah-istilah lokal, yang merupakan unsur-unsur dasar bahasa lokal, mencerminkan khasanah 
pengetahuan tertentu. Istilah-istilah dalam dunia tari Jawa di atas mencerminkan kearifan lokal Jawa, filosofi Jawa, pandangan hidup orang Jawa, mengenai tari-menari. Tari-menari dalam pandangan orang Jawa ternyata bukan hanya suatu kegiatan melakukan gerakan-gerakan tanpa makna. Tari-menari bagi orang Jawa dapat ditafsirkan sebagai kegiatan melakukan gerakan-gerakan yang dapat mewujudkan, mengekspresikan rasa atau keinginan, dalam kerangka suatu pandangan hidup tertentu.

Filsafat Jawa tentang tari yang tersimpan di balik berbagai katakata Jawa mengenai tari tersebut tentu dapat menjadi inspirasi bagi para penata tari (koreografer). Dengan memahami filsafat tari tersebut para penata tari dapat saja menciptakan komposisi-komposisi tari baru yang didasarkan pada filsafat tari di atas. Mereka juga dapat menjalan-kan profesi sebagai penari dengan menggunakan pandangan-pandangan hidup dan kearifan yang ada dalam filsafat tari tersebut sebagai landasannya.

\subsection{Sastra dan Kearifan Lokal}

Selain dalam bahasa, kearifan lokal juga tersimpan dalam karyakarya sastra lokal, baik yang lisan maupun tertulis. Sering dikatakan bahwa sastra merupakan gambar cermin dari masyarakat, terutama masyarakat pemilik sastra tersebut, sehingga mempelajari sastra, mulai dari mantra, pantun, peribahasa, hingga cerita rakyat dan novel, akan sangat membantu kita memahami pola pikir masyarakat atau berbagai kejadian dalam kehidupan masyarakat tersebut. Di sini saya mencoba menunjukkan bahwa dalam sastra tradisional kita dapat menemukan kearifan-kearifan lokal tertentu, yang belum tentu dapat kita temukan di tengah-tengah kehidupan sehari-hari mereka. Sastra tradisional tersebut adalah Babad Tanah Jawi. 
Jika kita membaca kitab klasik Babad Tanah Jawi ini misalnya, akan kita temukan di dalamnya berbagai berbagai ceritera menarik tentang tokoh-tokoh yang terkenal seperti Prabu Brawijaya II, Prabu Brawijaya IV, Sunan Ngampel, Sunan Geseng, maupun tokoh yang tidak begitu terkenal, seperti misalnya Ki Ajar Wilis, Putri Tanusekar, Murjangkung, Raden Jaka Dilah, dan sebagainya. Juga berbagai peristiwa bersejarah yang menarik, yang tidak semuanya terasa masuk akal, jika dipahami dengan kerangka berfikir orang sekarang. Salah satu episode yang menarik dalam Babad tersebut adalah episode pertemuan Sunan Kalijaga dengan Prabu Darmakusuma, atau Yudhistira, raja Amarta, putra sulung dalam keluarga Pandawa.

\subsubsection{Babad Tanah Jawi: Episode Prabu Darmakusuma dan Sunan Kalijaga}

Episode ini diawali dari upaya para wali di Jawa untuk membangun sebuah masjid, yang kini menjadi masjid yang terkenal, masjid Demak (lihat Santoso, 2003). Atas an-juran Sunan Giri para wali mendapat tugas untuk menyediakan empat sokoguru untuk masjid tersebut, yang tentu saja memerlukan kayu yang besar. Sunan Kalijaga, salah se-orang wali, kemudian pergi ke hutan. Ketika ia berjalan-jalan di hutan mencari kayu ter-sebut, beliau bertemu dengan seorang laki-laki dan perempuan.

Sunan Kali bertanya, "Siapakah tuan, dan apakah keperluan tuan tinggal di hutan belantara ini?"

Orang laki-laki itu menjawab, "Saya adalah Prabu Darmakusuma, raja Amerta. Siapakah tuan?"

Sunan Kali berkata dengan lembut "Saya adalah Seh Malaya. Mengapa tuan tidak mau pulang ke sorga?" 
Prabu Darmakusuma menjawab, "Saya belum dapat moksa, karena saya mempunyai sebuah jimat berupa "Surat Kalimasada". Kata Batara Guru kalau saya belum dapat membaca kitab itu, saya tak dapat moksa. Kelak akan ada orang yang bernama Seh Malaya yang dapat membaca surat itu. Kalau anda dapat membacanya, betul-betullah anda Seh Malaya. Kalau tidak, anda hanyalah orang yang mengaku-aku saja”.

Sunan Kali bertanya, "Bolehkah hamba melihat kitab Kalimasada itu?"

Kitab itu diberikan kepada Sunan Kali. Sudah barang tentu Sunan Kali dapat membacanya, karena Kalimasada itu pada hakekatnya adalah "kalimah syahadah".

Sunan Kali berkata, "Apakah tuanku hendak menganut Kalimasada ini? Kalimasada itu ilmu dari Hyang Suksma yang dianut oleh para wali"

Prabu Darmakusuma menjawab bahwa ia dan isterinya ingin menganut Kalimasada itu. Diajarilah Prabu Darmakusuma dan isterinya membaca kalimah syahadat, dan Islamlah mereka. Setelah mereka Islam, mereka dapat mati dengan tenang dan dikuburkan di tengah hutan" (Santoso, 2003: 92)

Episode di atas tentu dapat ditafsirkan dari berbagai sudut pandang. Seorang ilmuwan budaya yang meneliti tentang kearifan lokal dalam sastra tidak akan meremehkan atau menyangkal cerita di atas. Yang penting baginya bukanlah soal benar-tidaknya ceritera tersebut (karena benar dan tidaknya ceritera tersebut bersifat relatif), tetapi sebuah pendapat, sebuah teori bahwa sebuah ceritera pada dasarnya mencerminkan suatu pola pikir tertentu, karena sebuah ceritera adalah produk imajinasi manusia, produk pikiran manusia. Yang muncul dalam pikirannya kemudian adalah pertanyaan-pertanyaan: apakah ada kearifan tertentu di balik ceritera itu? Seperti apa kearifan tersebut? Mengenai apa kearifan itu kira-kira?.

Dengan cara analisis tertentu (lihat Ahimsa-Putra, 2007: 358) kisah di atas dapat ditafsirkan sebagai wujud dari upaya pikiran orang 
Jawa untuk menghubungkan dua perangkat pengetahuan, pandangan hidup dan sistem nilai yang unsur-unsurnya sebenarnya sulit, bahkan hampir tidak mungkin didamaikan. Sosok Sunan Kalijaga di situ dapat ditafsirkan sebagai representasi perangkat pandangan dan nilai Islam, sedang sosok prabu Yudhistira dengan istrinya dapat ditafsirkan sebagai representasi perangkat pengetahuan dan nilai pra-Islam, atau HinduBuddha (Ahimsa-Putra, 2007: 358). Dengan cara pandang seperti ini kisah Sunan Kalijaga dan Prabu Yudisthira di atas dapat ditafsirkan sebagai simbolisasi dari peralihan pandangan dan kehidupan orang Jawa, dari budaya pra-Islam ke budaya Islam dengan cara sukarela. Melalui ceritera seperti di atas orang Jawa berhasil menciptakan sebuah tirai ilusi bagi diri mereka sehingga dua perangkat pengetahuan dan sistem nilai tersebut menjadi tampak berhubungan satu sama lain, memiliki kesinambungan dan terasa tidak berlawanan.

Selanjutnya kita juga dapat menafsirkan bahwa kisah di atas menunjukkan suatu kearifan lokal, kearifan orang Jawa, untuk memahami sebuah proses perubahan kebudayaan, sebuah proses pergantian pandangan hidup dan sistem nilai. Dengan menciptakan ceritera seperti itu, orang Jawa lantas dapat menciptakan sebuah tirai budaya yang dapat mereka gunakan untuk memandang hidup dan kehidupan mereka dengan cara yang baru (Ahimsa-Putra, 2007: 371372). Inilah kearifan lokal mereka. Sebuah kearifan tentang cara merajut sebuah ilusi kolektif, sebuah dunia imajiner yang -bagaikan sebuah jaring- dapat mencegah kolektivitas mereka berantakan berkeping-keping tanpa sebuah ikatan (Ahimsa-Putra, 2008). 


\subsubsection{Babad Tanah Jawi: Episode Sunan Kalijaga, Katak dan Ular}

Contoh yang lain adalah episode pertemuan Sunan Kalijaga dengan katak dan ular. Bagian ini dapat ditafsirkan sebagai menyimpan sebuah kearifan yang begitu tersembu-nyi, sehingga tidak mudah diketahui. Alkisah, setelah Sunan Kalijaga bertemu prabu Darmakusuma dan isterinya, serta mengIslamkan keduanya, beliau berjalan kembali di hutan untuk mencari kayu besar yang akan dijadikan salah satu sokoguru masjid yang akan dibangun.

"Sunan Kali berjalan terus melihat-lihat pohon jati yang besar, tinggi dan lurus. Tiba-tiba terdengar suara katak berulang-ulang, dan ketika ia menoleh, dilihatnya seekor katak sedang hendak ditelan oleh seekor ular.

Sunan kali berkata, “huu..huu”. Ular itu melepaskan mangsanya, yang cepat-cepat lari menghindar. Ular berkata kepada Sunan Kali, "Sedang kami hendak menelan katak itu, tuanku berkata, "huu...huu”, apakah itu artinya?". "Saya hendak mengatakan, "(H)u-lunen.. (telanlah)". Ular tak menjawab lagi, lalu pergi.

Kemudian katak yang tertolong dari bahaya maut itu datang untuk mengucapkan terima kasih. "Tuanku, hamba mengucapkan banyakbanyak terimakasih atas pertolongan tuanku itu Tapi bolehkah hamba mengetahui apa arti kata "huu...huu” yang tuan ucapkan itu?". Sunan Kali berkata, "Aku hendak mengatakan (h)uculnaa..(h)uculnaa.." (lepaskanlah..lepaskanlah...!)

Katak berkata, "Hamba merasa sangat berhutang budi kepada tuanku. Oleh karena itu hamba berjanji akan membawa kayu yang tuanku pilih itu ke kota Bintara, bila telah siap". Sunan Kali menjawab, "Terimakasih ...katak..." (Santoso, 2003: 92-94)

Sebuah fragmen yang aneh tetapi sangat menarik, yang mungkin akan membuat sebagian orang berkata, "Ah..itu kan cuma dongeng..mana mungkinlah manusia bisa berbicara dengan binatang". Terlepas dari benar-tidaknya kisah itu, yang perlu direnungkan adalah nilai-nilai apa yang ada di balik ceritera tersebut, yang mungkin masih relevan dengan 
kehidupan kita sekarang, sehingga kita akan dapat mengupayakan reaktualisasinya.

Dari sudut pandang tertentu, kisah Sunan Kalijaga di atas dapat ditafsirkan sebagai sebuah ajaran tentang cara menyelesaikan sebuah perselisihan, sebuah pertikaian yang tidak seimbang antara pihak yang sangat kuat dan sangat lemah, namun dengan hasil yang dapat diterima oleh semua pihak, atau dengan istilah sekarang win-win solution. Penyelesaian semacam ini memungkinkan pihak yang berselisih samasama merasa tidak kalah, tidak kehilangan muka, dan karena itu lantas dapat diterima oleh kedua belah pihak (Ahimsa-Putra, 2009).

Mungkin ada yang tidak setuju dengan tafsir ini, dan justru berpendapat bahwa Sunan Kalijaga dalam kisah itu tampak "bermuka dua" atau mencla-mencle. Pendapat seperti ini tidak salah. Akan tetapi, atas dasar pendapat seperti itupun tidak berarti bahwa apa yang telah dilakukan oleh Sunan Kalijaga adalah hal yang buruk dalam konteks ceritera di atas, karena "bermuka dua" di situ tidak untuk mengadudomba atau menimbulkan perselisihan, tetapi justru untuk menyelamatkan pihak yang lemah, tanpa membuat pihak yang lebih kuat merasa dirugikan atau kehilangan muka. Apa yang dilakukan oleh Sunan Kalijaga dapat ditafsirkan sebagai sebuah tindakan yang didasarkan pada nilai-nilai (a) bahwa menyelesaikan sengketa antara pihak yang lemah dengan pihak yang lebih kuat adalah perbuatan yang baik, yang perlu dilakukan; (b) bahwa pertolongan sebaiknya diberikan dengan cara yang dapat membuat kedua pihak yang bersengketa merasa diuntungkan atau minimal tidak merasa dirugikan oleh yang menengahi sengketa. Inilah kearifan lokal yang dapat kita tangkap dari episode di atas (AhimsaPutra, 2009). 


\section{Penutup}

Analisis atas bahasa daerah dan sastra daerah tradisional di atas menunjukkan bahwa dalam bahasa dan sastra daerah tersebut terdapat berbagai kearifan lokal yang dapat dimanfaatkan untuk menyelesaikan masalah-masalah praktis, seperti penerjemahan kata-kata asing ke dalam bahasa Indonesia, di samping kearifan-kearifan lokal yang dapat menjadi sumber inspirasi penciptaan karya-karya seni tertentu atau menawarkan cara-cara penyelesaian masalah-masalah sosial tertentu. Bahasa dan sastra daerah di Indonesia yang begitu banyak merupakan khasanah pengetahuan yang pasti menyimpan ba-nyak sekali kearifan-kearifan lokal yang lain. Adalah tugas para ilmuwan sosial-budaya untuk mengungkap berbagai kearifan tersebut, menunjukan manfaatnya bagi peningkatan kualitas kehidupan manusia, dan menyajikannya kepada masyarakat sedemikian rupa agar mudah dipahami dan dimanfaatkan.

Tantangan besar yang dihadapi oleh para ilmuwan sosial-budaya di sini adalah menentukan dan membangun metode analisis yang dapat digunakan untuk mengungkap kearifan-kearifan lokal pada tataran fonem, morfem, leksikon, dari berbagai bahasa daerah yang ada di Indonesia. Analisis komponen seperti di atas hanyalah salah satu contoh kecil dan sederhana dari metode analisis linguistik yang dapat diterapkan. Tantangan berikutnya adalah menentukan dan mengembangkan metode analisis hermeneutik yang dapat menghasilkan tafsir yang pas untuk wacana-wacana yang berhasil dihimpun. Walaupun analisis hermeneutis di atas tampak sudah sesuai, namun metode seperti itu masih perlu diuraikan dengan lebih rinci agar tahap-tahapnya dapat diikuti dengan mudah oleh peneliti-peneliti yang lain.

Persoalannya sekarang adalah: apakah bahasa-bahasa lokal yang ada telah berhasil dihimpun, kemudian disusun secara sistematis dan 
dianalisis? Apakah seluruh sastra lokal yang ada telah berhasil dihimpun, didokumentasikan secara rapi dan sistematis, dan kemudian dianalisis? Apakah analisis-analisis yang ditujukan untuk mengungkapkan berbagai kearifan lokal di dalamnya juga telah dilakukan? Tidak ada yang dapat menjawab pertanyaan-pertanyaan ini kecuali para ahli bahasa, sastra dan ahli kebudayaan Indonesia pada umumnya.

\section{Daftar Pustaka}

Ahimsa-Putra, H.S.. 2000a. Bahasa Jawa dan Bahasa Ratahan di Tengah Arus Perubahan. Makalah seminar.

. 2000b. "Islam Jawa dan Jawa Islam: Sinkretisasi Agama di Jawa". Tembi 1 Thn.I: 10-19.

. 2002a. Potensi Budaya Lokal Sebagai Sumber Penataan Sosial. Makalah Temu Budaya

. 2004a. Kearifan Tradisional dan Lingkungan Sosial. Makalah seminar.

. 2004b. "Etnosains: Mengungkap Pengetahuan Masyarakat Pedesaan". Dinamika Pedesaan dan Kawasan 4 (4): 34-45.

2005. Kearifan Tradisional dan Lingkungan Fisik. Makalah lokakarya.

. 2007. "Etnosains, Etnotek dan Etnoart: Paradigma Fenomenologis Untuk Revitalisasi Kearifan Lokal" dalam Kemajuan Terkini Riset Universitas Gadjah Mada, Jumina dan Danang Parikesit (eds.). Yogyakarta: LPPM-UGM.

. 2008a "Kata Pengantar" dalam Kearifan Tradisional Masyarakat Pedesaan dalam Pemeliharaan Lingkungan Alam, Kabupaten Gunung Kidul, Provinsi Daerah Istimewa Yogyakarta. 
57 Mabasan - Vol. 3 No. 1 Januari-Juni 2009: 30--57

Jakarta: Direktorat Jenderal Seni dan Film, Departemen Kebudayaan dan Pariwisata.

. 2008b. Ilmuwan Budaya dan Revitalisasi Kearifan Lokal: Tantangan Teoritis dan Metodologis. Pidato Ilmiah Dies Natalis Fakultas Ilmu Budaya, UGM

. 2008c. Nilai-nilai Luhur Budaya Jawa: Tantangan Dalam Reaktualisasinya Pidato Ilmiah Dies Natalis Fakultas Sastra dan Seni, Universitas Negeri Sebelas Maret.

. 2008d. Nilai Budaya Lokal di Era Global: Tantangan dan Peluang. Makalah Dialog Budaya.

Poerwadarminta, W.J.S. Kamus Umum Bahasa Indonesia. Jakarta: Balai Pustaka.

Santoso, S. 2003. Babad Tanah Jawi (Galuh-Mataram). Surakarta: STSI Surakarta.

Suharto, B. 1995. "Javanese Dance: Cosmology and Aesthetics" dalam Traditional Theatre in Southeast Asia, C.S.Pong (ed). Singapore: UniPresSPAFA. 